\title{
VI. IN MEMORIAM
}

\section{Wspomnienie o Profesorze zwyczajnym doktorze habilitowanym Bogusławie Banaszaku}

Kreślenie niniejszych słów o Panu Profesorze Bogusławie Banaszaku wydaje się niczym zły sen. Jeszcze w październiku 2017 r. wspólnie z Panem Profesorem świętowaliśmy Jubileusz 40-lecia Jego pracy naukowej. Dziś wspominamy Pana Profesora, bo 9 stycznia 2018 r. nagle od nas odszedł. Ta nagła i zdecydowanie przedwczesna śmierć Profesora oraz nieoczekiwana przez nikogo informacja o niej wzbudziła poczucie ogromnego żalu, z trudem pozwalającego pogodzić się z utratą wspaniałego nauczyciela akademickiego i przyjaciela wielu pokoleń nie tylko konstytucjonalistów zarówno polskiego, jak i zagranicznego środowiska naukowego. Zrodziła żal za spotkaniami, za niemożnością przedyskutowania materii objętej badaniami naukowymi, żal za wymianą poglądów i rozmowami, tymi codziennymi i niecodziennymi, w sprawach ważnych i mniej ważnych, zawsze podyktowanymi życzliwością wobec swoich rozmówców. Pan Profesor Bogusław Banaszak był osobą niezwykle przyjazną, a jednocześnie realistycznie nastawioną do wydarzeń otaczających Go zmian, dokładającą wielu starań w rozwiązywanie spraw, z którymi przyszło Mu się zmierzyć. Bez wątpienia był osobą, której dom rodzinny oraz z żelazną konsekwencją i zaangażowaniem później realizowany własny rozwój naukowy, przy dużym wsparciu Małżonki, pozwoliły na wyznaczenie drogi zarówno tej życiowej, jak i tej na niwie zawodowej (naukowej).

Pan Profesor Bogusław Banaszak urodził się 3 lutego 1955 r. we Wrocławiu w rodzinie lekarskiej. Nie tylko dzieciństwo i młodość, ale również przeważająca część Jego dorosłego życia związane były ze stolicą Dolnego Śląska. Już w młodości wykazywał zainteresowanie nauka, co skutkowało ukończeniem III Liceum Ogólnokształcącego we Wrocławiu 
z brązowym medalem za wyniki w nauce. Studia prawnicze także odbywał (w latach 1973-1977) w tym mieście i ukończył je z wyróżnieniem.

Zaraz po studiach - w 1977 r. - podjął pracę na stanowisku asystenta stażysty na Wydziale Prawa i Administracji Uniwersytetu Wrocławskiego. Następnie kolejno zajmował stanowiska asystenta i starszego asystenta, a po obronie rozprawy doktorskiej i uzyskaniu stopnia doktora nauk prawnych (1983 r.) został adiunktem (1984 r.). W $1991 \mathrm{r} . \mathrm{z}$ powodzeniem przebył postępowanie habilitacyjne i od $1994 \mathrm{r}$. awansował na stanowisko profesora nadzwyczajnego Uniwersytetu Wrocławskiego. Tytuł profesora nauk prawnych otrzymał w 1998 r. Pracę na Wydziale Prawa, Administracji i Ekonomii na stanowisku profesora zwyczajnego kontynuował do 2014 r., tj. do czasu objęcia funkcji dziekana Wydziału Prawa i Administracji Uniwersytetu Zielonogórskiego. Od samego początku zainteresowania badawcze prof. Bogusława Banaszaka obejmowały prawo konstytucyjne, prawo parlamentarne i prawa człowieka.

W okresie zatrudnienia na Uniwersytecie Wrocławskim prof. Bogusławowi Banaszakowi powierzano pełnienie licznych i odpowiedzialnych funkcji. Od 1996 do 2002 r. przewodniczył Uczelnianej Komisji Wyborczej Uniwersytetu Wrocławskiego i kierował studiami doktoranckimi na rodzimym wydziale. W 2002 r. objął obowiązki kierownika Katedry Prawa Konstytucyjnego, którym był do końca pracy na Wydziale Prawa, Administracji i Ekonomii Uniwersytetu Wrocławskiego. W 2002 r. był także prodziekanem na tym Wydziale. W latach 2002- 2006 sprawował funkcję Koordynatora Szkoły Prawa Niemieckiego i Prawa Polskiego, stanowiącej wspólne przedsięwzięcie wydziałów prawa Uniwersytetu Wrocławskiego i Uniwersytetu im. Humboldta w Berlinie. Następnie od 2006 do 2014 r. był pełnomocnikiem Dziekana do spraw tej Szkoły.

Naukowo-dydaktyczna droga prof. Bogusława Banaszaka wiodła także przez inne krajowe i zagraniczne ośrodki naukowe. W latach 1995-2005 był profesorem w Wyższej Szkole Zarządzania i Marketingu we Wrocławiu, a w latach 1999-2002 pełnił funkcję prorektora tej uczelni. Przez dziesięć lat (od 1998 do 2008 r.) pracował jako profesor na Wydziale Prawa Europejskiego Uniwersytetu Viadrina (we Frankfurcie nad Odrą), gdzie kierował Katedrą Polskiego Prawa Publicznego. Od 2005 r. Pan Profesor był związany z Państwową Wyższą Szkołą Zawodową im. Witelona w Legnicy. W latach 2012-2014 został Pełnomocnikiem Rektora Uniwersytetu Zielonogórskiego (UZ) dla utworzenia Wydziału Prawa i Administracji na Uniwersytecie Zielonogórskim. Jak każde swoje zadanie, tak i to udało mu się z sukcesem zrealizować. 
Wydział Prawa i Administracji UZ zainaugurował swoją działalność 1 października 2014 r. Od września tego roku zatrudniony był jako profesor zwyczajny Uniwersytetu Zielonogórskiego, pełniąc aż do śmierci obowiązki dziekana Wydziału Prawa i Administracji na tym Uniwersytecie. Od początku istnienia tego Wydziału kierował też Katedrą Prawa Konstytucyjnego.

Obecność prof. Bogusława Banaszaka w Zielonej Górze pozytywnie wpłynęła na jej rozwój. Nadto swoją osobą Pan Profesor działał - bardzo skutecznie - na rzecz pogłębienia współpracy władz samorządowych i organów państwowych z Uniwersytetem Zielonogórskim. Swoim optymizmem i zaangażowaniem w pracę nad wciąż kształtowanym Wydziałem zarażał bliższych i dalszych współpracowników. Z sukcesem doprowadził do przekazania na potrzeby Wydziału Prawa i Administracji UZ odrestaurowanego zabytkowego budynku na pl. Słowiańskim. Studenci zdobywają dzięki temu wiedzę w sercu aktywności zielonogórskiego środowiska prawniczego - w otoczeniu sądów. Sam jednak nie zdążył zasiąść w gabinecie dziekańskim w nowej siedzibie.

Pan Profesor był członkiem licznych towarzystw naukowych. Należały do nich: Argentyńskie Stowarzyszenie Prawa Konstytucyjnego (Asociacion Argentina de Justicia Constitucional, AAJC - od 2016 r.), Europejskie Stowarzyszenie Prawa Wyborczego (od 2004 r.), Polskie Stowarzyszenie Prawa Europejskiego (od 2004 r.), Societas Iuris Publici Europaei (Międzynarodowe Towarzystwo Naukowe z siedzibą zarządu w Getyndze (od 2003 r.), Stowarzyszenie Prawników Ukrainy (od 2011 r.), Światowe Stowarzyszenie Prawników (World Jurist Association - od 2011 r.) oraz Honorowy Instytut Prawa Interdyscyplinarnego Fakultetu Prawa Uniwersytetu w Porto (Portugalia, od 2006 r.). W latach 2006-2010 był członkiem Rady Rzecznika Praw Obywatelskich.

Działalność Pana Profesora nie ograniczała się jednak li tylko do aktywności naukowej. Z największym oddaniem współpracował z licznymi instytucjami, organami i organizacjami, służąc dobru ojczyzny. Od 1992 r. stale współpracował ze służbami legislacyjnymi parlamentu, będąc autorem kilkudziesięciu ekspertyz sporządzanych dla naczelnych organów władz publicznych. Był członkiem Komisji Kodyfikacyjnej Prawa Rodzinnego działającej przy Rzeczniku Praw Dziecka (od 2013 r.). Przede wszystkim podkreślić należy, że od maja 2006 do maja 2010 r. był Przewodniczącym Rady Legislacyjnej przy Prezesie Rady Ministrów, zaś od kwietnia 2016 r. członkiem Rady Legislacyjnej przy Prezesie Rady Ministrów. Od kwietnia 2016 r. był również członkiem 
Europejskiej Komisji na rzecz Demokracji przez Prawo (tzw. Komisja Wenecka), członkiem tytularnym Grupy Niezależnych Ekspertów do spraw Europejskiej Karty Samorządu Terytorialnego Rady Europy Strasbourg (Group of Independent Experts on the European Charter of Local Self-Government - Council of Europe; od kwietnia 2013 r.), członkiem Trybunału Stanu (od 2017 r.).

Ponadto Pan Profesor był członkiem zarządu (Steering Committee) Euro-Faculty w Rydze (1992-1998), ekspertem Państwowej Komisji Akredytacyjnej (2010-2014), członkiem korespondentem hiszpańskiej Królewskiej Akademii Nauk Moralnych i Politycznych (od 2010 r.) oraz Europejskiej Akademii Nauki, Sztuki i Literatury w Paryżu (od 2004 r.), a ponadto członkiem Komitetu Nauk Prawnych Polskiej Akademii Nauk (od 2011 r.), Rady Doradczej do spraw Praw Człowieka przy Ministrze Spraw Zagranicznych (2000-2001), Rady Programowej Centrum Studiów Wyborczych Uniwersytetu Łódzkiego i Uniwersytetu Mikołaja Kopernika w Toruniu (2008-2016), Międzynarodowego Dyrektoriatu Doradczego (Advisory Directorate International) Amerykańskiego Instytutu Biograficznego (od 2009 r.) oraz Zespołu Specjalistycznego Nauk Humanistycznych, Społecznych i Nauk o Sztuce i Twórczości Artystycznej (utworzonego przez Ministra Nauki i Szkolnictwa Wyższego - od stycznia 2017 r.).

Pan Profesor był autorem ponad trzystu prac naukowych, wśród których są monografie, podręczniki, komentarze i studia oraz artykuły. Podręcznik do prawa konstytucyjnego Jego autorstwa należy do kanonu polskiej literatury prawniczej, z którego uczą się kolejne pokolenia prawników. Kilkadziesiąt prac Profesora opublikowano za granicą (na Węgrzech, w Austrii, Brazylii, Niemczech, Chile, Korei Południowej, Holandii, Rumunii, we Francji i Włoszech). Ponadto Profesor Banaszak przetłumaczył na język polski dziewięć książek prawniczych i kilkadziesiąt artykułów, głównie z języka niemieckiego oraz angielskiego. Kolejnym polem aktywności Profesora była współpraca z licznymi czasopismami naukowymi. Był redaktorem „Przeglądu Prawa i Administracji" wydawanego we Wrocławiu (1996-2008), przewodniczącym komitetu redakcyjnego „Przeglądu Legislacyjnego" (od czerwca 2006 do czerwca 2010 r.). Pełnił także funkcję członka kolegiów (rad) redakcyjnych: "Recht in Ost und West” (Niemcy, 1991-1998), "Osteuropa Recht" wydawanego w Kolonii (Niemcy, od 1998 r.), "Humanistycznych Zeszytów Naukowych - Prawa Człowieka" wydawanych w Katowicach (od 2000 r.), "Studiów Wyborczych" wydawanych w Łodzi (od 2006 r.), 
„Közjogi Szemle” kwartalnika wydawanego w Budapeszcie (od 2008 r.), "Annales Universitatis Apulensis. Series Jurisprudentia" wydawanych w Alba Julii (Rumunia, od 2008 r.), „Pravo Ukrainy” wydawanego w Kijowie (Ukraina, od 2011 r.), „Revista da Faculdade de Direito de Sao Bernardo do Campo" wydawanego w Sao Paulo (Brazylia, od 2011 r.), "Comparative Law Review" (czasopisma Wydziału Prawa i Administracji Uniwersytetu Mikołaja Kopernika w Toruniu, od 2013 r.), "Radca Prawny. Zeszyty Naukowe" (od 2014 r.) oraz od 2015 r. kwartalnika „Studia Prawa Publicznego" i „Rocznika Stowarzyszenia Naukowców Polaków Litwy".

Pan Profesor Bogusław Banaszak aktywnie uczestniczył w życiu naukowym nie tylko w Polsce i w Europie, ale i na innych kontynentach. Wygłosił ponad 150 wykładów gościnnych na ponad dwudziestu uniwersytetach europejskich (Austria, Niemcy, Portugalia, Szwajcaria, Węgry, Wielka Brytania, Hiszpania, Ukraina, Włochy, Rumunia) i amerykańskich (Stany Zjednoczone, Brazylia, Chile, Ekwador, Meksyk). W semestrze letnim 1994 r. był profesorem gościnnym na Uniwersytecie Wiedeńskim. Był autorem lub współautorem blisko stu referatów wygłaszanych na międzynarodowych konferencjach naukowych (Austria, Brazylia, Chile, Francja, Litwa, Łotwa, Niemcy, Rumunia, Syria, Szwajcaria, Ukraina, Węgry, Włochy, Tajwan).

Za swoją działalność Pan Profesor był wielokrotnie odznaczany w 2000 r. Wielkim Krzyżem Zasługi Republiki Austrii, w 2001 r. Złotym Krzyżem Zasługi RP, w 2007 r. Wielką Złotą Odznaką Honorową za Zasługi dla Republiki Austrii, w 2008 r. Krzyżem Kawalerskim Orderu Odrodzenia Polski oraz niemieckim Federalnym Krzyżem Zasługi na Wstędze, w 2011 r. zaś Austriackim Krzyżem Honorowym Nauki i Sztuki I klasy, a także Orderem Sprawiedliwości I stopnia Światowego Stowarzyszenia Prawników. Prezydent Rzeczypospolitej Polskiej Andrzej Duda odznaczył pośmiertnie prof. Banaszaka Krzyżem Oficerskim Orderu Odrodzenia Polski.

Profesor Bogusław Banaszak był doktorem honoris causa Uniwersytetu w Pecs (Węgry - 2004 r.), Uniwersytetu w Alba Julii (Rumunia - 2009 r.), Uniwersytetu w Pitesti (Rumunia - 2010 r.) i Kijowskiego Uniwersytetu Prawa (Ukraina - 2011 r.).

W kraju dwukrotnie Minister Edukacji Narodowej wyróżniał Pana Profesora Nagrodami Indywidualnymi - w 2000 r. za podręcznik Prawo konstytucyjne i w 2004 r. za wydane w języku niemieckim Wprowadzenie do polskiego prawa konstytucyjnego. Za badania nad prawem austriackim 
i prawem konstytucyjnym państw demokratycznych został wyróżniony też w 2004 r. austriacką nagrodą im. Leopolda Kunschaka. Nie sposób zliczyć przyznawanych co roku nagród JM Rektora Uniwersytetu Wrocławskiego za osiągnięcia naukowe, dydaktyczne i organizacyjne.

Pan Profesor wypromował czterdziestu doktorów (w tym pięciu w uczelniach niemieckich) i ponad czterystu magistrów. Sprawował funkcję recenzenta w kilkudziesięciu przewodach doktorskich i postępowaniach habilitacyjnych. Przygotował także kilkadziesiąt opinii (recenzji) w postępowaniach o nadanie tytułu profesora lub w sprawach zatrudnienia (przedłużenia zatrudnienia) na stanowisku profesora nadzwyczajnego.

Aktywność zawodowa, a jak wynika z przedstawionego opisu - była ona imponująca, nigdy nie spowodowała odsunięcia na dalszy plan życia prywatnego - a zwłaszcza rodzinnego. Najbliższym Panu Profesorowi osobom, w tym zwłaszcza ukochanej żonie Bożenie, córce Agnieszce wraz z mężem oraz wnukom, zawsze poświęcał największą uwagę. Żona towarzyszyła Panu Profesorowi w większości wyjazdów. Była obecna podczas wszystkich najważniejszych dla Profesora uroczystości. Miłość i szacunek panujące w rodzinie Banaszaków były widoczne gołym okiem. Stosunki rodzinne oddziaływały zresztą także na wszystkie inne relacje Pana Profesora. Wobec każdego odnosił się z szacunkiem. Różnice poglądów nie przysłaniały najważniejszej wartości, jaką jest człowiek i jego przyrodzona godność. Każdy, kto choć przez chwilę zetknął się z Panem Profesorem, rozumie w pełni sens powyższych słów. Pracownicy Katedry Prawa Konstytucyjnego i Wydziału (najpierw Prawa, Administracji i Ekonomii Uniwersytetu Wrocławskiego, później Prawa i Administracji UZ) byli dla Pana Profesora współpracownikami. Swoich wychowanków włączał do prowadzonych prac i nigdy o nich nie zapominał. Niejednokrotnie z pełnym życzliwości zainteresowaniem dzwonił, pisał lub spotykał się, aby porozmawiać o problemach dnia codziennego. Służył pomocą i nigdy jej nie odmawiał. Nie zawsze mógł rozwiązać kłopot, ale dobre słowo dawało siłę.

$Z$ równie dużym szacunkiem i atencją współpracował z redakcją czasopisma naukowego "Studia Prawa Publicznego", początkowo jako recenzent, później członek jej Rady Naukowej, przysparzając czasopismu znaczną rangę nie tylko przez publikowanie na jego łamach własnych artykułów, ale i stwarzając warunki do publikacji opracowań innych wybitnych specjalistów nauki z Europy i świata. Niezwykle wartościowa była także współpraca z Profesorem podczas wspólnych wizyt akredytacyjnych Zespołu nauk społeczno-prawnych Polskiej Komisji 
Akredytacyjnej, nacechowanych nie tylko Jego rzetelnością w wykonywaniu powierzonych zadań, ale też ogromną pokorą wobec pracowników akredytowanych szkół wyższych, stanowiącą coraz rzadszą cechę wśród ludzi nauki.

O tym, jakim człowiekiem, a przede wszystkim przyjacielem był Pan Profesor, świadczy liczba uczestników Jubileuszu 40-lecia Jego pracy naukowej. W samych uroczystościach wzięło udział ponad 250 osób, w tym wielu przedstawicieli najwyższych organów państwowych i zagranicznych. O szerokim gronie osób, których przyjaźnią Pan Profesor cieszył się na całym świecie, świadczy objętość dwóch tomów księgi jubileuszowej. Teksty złożyło ponad stu autorów nie tylko z Polski i innych państw europejskich, ale nawet $\mathrm{z}$ najodleglejszych krajów świata - Brazylii czy Tanzanii. Swoją osobowością i postawą Pan Profesor zjednywał sobie także studentów. Wszystkie wykłady cieszyły się niespotykaną na uczelniach wyższych popularnością. Niejednokrotnie Pan Profesor był wyróżniany przez studentów nagrodą dla najlepszego wykładowcy. Te wyróżnienia cieszyły Profesora ogromnie.

W dwa miesiące po śmierci nadal chcemy sięgnąć po telefon i zadzwonić. Już nigdy go niestety nie odbierze. Nie odczyta również naszych e-maili, ale i my nie otrzymamy od niego wiadomości z załącznikami pouczającymi i cieszącymi ich zawartością. Jest jednak z nami. Zachowujemy prof. Bogusława Banaszaka we wspomnieniach i naukach, które po sobie zostawił. Panie Profesorze, pozostanie Pan w naszych myślach i sercach! Spoczywaj w pokoju! 